\title{
PENGGUNAAN SISTEM PENYIMPANAN MODIFIKASI ATMOSFIR UNTUK MEMPERTAHANKAN DAYA A WET IKAN KAKAP MERAH (Lutjanus spp) SEGAR
}

\author{
M.Rizal Chatib"), Rizal Syarief $\left.{ }^{* *}\right)$, Endang Sri Heruwati $\left.{ }^{* * *}\right)$, Abu Naim Assik ${ }^{* * * *}$ )
}

\begin{abstract}
ABSTRAK
Pengaruh sistem penyimpanan modifikasi atmosfir dengan meninggikan tingkat konsentrasi $\mathrm{CO}_{2}$ telah dipelajari dalam mempertahankan mutu ikan kakap merah (Lutjanus spp) segar. Percobaan dilakukan dengan menggunakan konsentrasi $\mathrm{CO} 260 \%$ dan $40 \%$ dalam udara, dibandingkan dengan penyimpanan dalam udara normal pada suhu $2^{\circ} \mathrm{C}$. Hasilnya diperoleh bahwa, perubahan kimiawi dan mikrobiologis ikan berkorelasi dengan perubahan organoleptik berdasarkan penilaian panelis baik pada ikan mentah maupun ikan kukus. Setelah 21 hari penyimpanan; konsentrasi TVB, TMA, pH, total bakteri aerob, total bakteri anaerob, total bakteri gram positif dan total bakteri gram negatif lebih rendah pada ikan kakap merah segar yang disimpan dalam atmosfir dengan $60 \% \mathrm{CO}_{2}$ dibandingkan dengan sampel yang disimpan dalam $40 \%$ $\mathrm{CO}_{2}$ atau dalam udara normal.
\end{abstract}

\section{ABSTRACT: Modified Atmosphere Storage of Fresh Red Snapper (Lutjanus spp), by: M.Rizal Cbatib, Rizal Syarief, Endang Sri Heruwati, Abu Naim Assik}

The effect of modified atmosphere storage using elevated $\mathrm{CO}_{2}$ level on the quality of fresh whole red snapper fish (Lutjanus spp) was studied. Experiments were conducted using modified atmospheres at levels of $60 \%$ and $40 \% \mathrm{CO}_{2}$ compared to common air storage at $2^{\circ} \mathrm{C}$. It was found that the chemical and microbiological changes were in correlation with the scores of sensory panel evaluations of raw fish and steamed fish. After 21 days of storage the TVB, TMA, pH values as well as the figures of total aerobic, anaerobic, gram positive and gram negative bacteria were lower in fresh red snapper stored in $60 \% \mathrm{CO}_{2}$ as compared to samples stored in $40 \% \mathrm{CO}_{2}$ or in common air storage.

KEYWORDS: Modified atmosphere storage, fresh fish, food packaging

\section{PENDAHULUAN}

Produksi perikanan laut Indonesia cenderung meningkat setiap tahun. Namun karena sifat ikan yang mudah busuk (highly perishable), maka diperlukan suatu kegiatan penanganan yang tepat setelah ikan ditangkap, agar peningkatan produksi yang diperoleh tidak menjadi sia-sia.

Penanganan ikan segar dengan suhu dingin yang umum dilaksanakan selama ini, dalam beberapa hal masih belum memberikan hasil yang memuaskan, terutama dari aspek umur simpan dan mutu kesegaran ikan yang dapat diterima oleh konsumen. Untuk itu akhir-akhir ini mulai dikembangkan suatu alternatif mempertahankan daya awet ikan segar dengan menggabungkan

\footnotetext{
*) Pengajar pada Universitas Bung Hatta, Padang

mepala Pusat Pengembangan Teknologi Pangan IPB, Bogor

*n*) Peneliti pada Balai Penelitian Perikanan Laut, Jakarta

*****) Pengajar pada Fakultas Perikanan IPB, Bogor
} 
suhu dingin dengan penyimpanan modifikasi atmosfir (modified atmosphere storage, MAS).

Metode MAS dilaksanakan dengan melakukan penggantian udara di sekeliling produk oleh gas-gas lain, biasanya $\mathrm{CO}_{2}, \mathrm{O}_{2}$, dan $\mathrm{N}_{2}$ secara sendirisendiri atau dalam suatu kombinasi. Di antara gas-gas tersebut, $\mathrm{CO}_{2}$ (dengan level yang ditingkatkan) ditemukan lebih efektif untuk perlindungan makananmakanan dari daging, disebabkan oleh efek $\mathrm{CO}_{2}$ yang dapat menghambat/ menekan pertumbuhan bakteri (Jensen et al., 1980).

Hasil penekanan pertumbuhan bakteri ini, mempengaruhi pula penekanan level indikator-indikator pembusukan secara kimiawi, seperti Trimethylamine (TMA), Total Volatile Bases (TVB), dan Total Volatile Nitrogen (TVN) (Banks et al., 1980).

Beberapa hasil penelitian pada berbagai jenis ikan memperlihatkan bahwa penyimpanan secara MAS dapat menghambat perubahan-perubahan fisik, kimiawi, dan mikrobiologis penyebab kemunduran produk. Penghambatan ini telah mengakibatkan meningkatnya daya simpan produk antara $50 \%$ dan $100 \%$ (Statham, 1984). Peningkatan daya simpan ikan segar secara MAS ini dipengaruhi oleh: spesies, kualitas awal ikan sebelum disimpan, suhu penyimpanan, jenis gas, dan konsentrasi campuran gas yang digunakan (Cann, 1988).

Penelitian ini bertujuan untuk mempelajari pengaruh tingkat konsentrasi $\mathrm{CO}_{2}$ dan jenis kemasan yang berbeda terhadap mutu kesegaran ikan kakap merah, menentukan tingkat konsentrasi $\mathrm{CO}_{2}$ dan jenis kemasan yang cocok untuk mempertahankan daya awet ikan, dan mengetahui umur simpan ikan kakap merah segar secara MAS pada suhu $2^{\circ} \mathrm{C}$.

\section{BAHAN DAN METODE}

\section{Bahan Penelitian}

Bahan yang digunakan untuk penelitian adalah: ikan kakap merah segar sebanyak 96 ekor (berat rata-rata 465 gram, panjang $26 \mathrm{~cm}$ ) diambil dari TPI Muara Angke Jakarta; gas $\mathrm{CO}_{2}$ dan $\mathrm{O}_{2}$; plastik OPP dan PVC, serta bahanbahan kimia untuk analisis di laboratorium.

\section{Metode Penelitian}

\section{- Penelitian dilakukan 2 tahap:}

Penelitian tahap pertama; bertujuan untuk mengetahui kisaran tingkat konsentrasi $\mathrm{CO}_{2}$ yang optimum bagi penyimpanan ikan kakap merah segar, yang selanjutnya akan digunakan pada penelitian tahap kedua. Konsentrasi $\mathrm{CO}_{2}$ yang diuji pada tahap ini adalah $30 \%, 40 \%, 50 \%, 60 \%, 80 \%$, dan $100 \%$. 
Penelitian tahap kedua; dimaksudkan untuk mempelajari pengaruh tingkat konsentrasi $\mathrm{CO}_{2}$ dan jenis kemasan terhadap mutu kesegaran ikan kakap merah segar, serta menentukan tingkat konsentrasi $\mathrm{CO}_{2}$ dan jenis kemasan yang cocok dan lamanya umur simpan yang layak untuk mempertahankan daya awet ikan pada suhu $2^{\circ} \mathrm{C}$. Perlakuan yang digunakan pada tahap ini adalah: Gas $\mathrm{CO}_{2}$ (G): $\mathrm{G} 1=60 \% \mathrm{CO} 2$ dalam udara, $\mathrm{G} 2=40 \% \mathrm{CO}_{2}$ dalam udara dan $\mathrm{G} 3=$ kontrol (udara normal); Kemasan plastik (P): $\mathrm{P} 1=$ plastik OPP(oriented polypropylene), P2 = plastik PVC (polyvinyl chloride); Lama penyimpanan (L): L1 = 0 hari, L2 = 7 hari, L3 = 14 hari dan L4 = 21 hari.

\section{Teknik Pengemasan MAS}

Setelah diturunkan dari kapal, ikan dipilahkan untuk mendapatkan yang berkualitas sangat bagus dan berukuran seragam. Ikan tersebut kemudian dimasukkan ke dalam kotak berinsulasi dan diberi hancuran es secukupnya. Selanjutnya ikan dibawa ke laboratorium untuk disiangi dan dicuci bersih. Kemudian ikan dimasukkan ke dalam kemasan plastik PVC sebanyak dua ekor ikan per kemasan. Kemasan plastik tersebut diberi alas kotak polysterena untuk menghindari kerusakan plastik kemasan oleh sirip dan sisik ikan. Selama dalam pengangkutan dan penanganan di laboratorium suhu ikan selalu dipertahankan tetap sekitar $0^{\circ} \mathrm{C}$.

Ikan yang sudah dikemas kemudian diberi gas $\mathrm{CO}_{2}$ dan $\mathrm{O}_{2}$ dengan menggunakan cosmotector tipe XPO-317 dan XP-314 serta flowmeter. Kadar $\mathrm{CO}_{2}$ sesuai dengan perlakuan yang dipilih, sedangkan kadar $\mathrm{O}_{2}(\%)$ ditetapkan sbb:

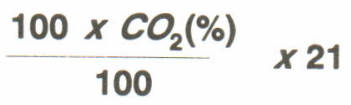

Setiap perlakuan diulang dua kali, selanjutnya kemasan disimpan di ruang pendingin pada suhu $2^{\circ} \mathrm{C}$ untuk dilakukan pengamatan pada waktu-waktu tertentu yang telah ditetapkan.

\section{Pengamatan}

Pengamatan dilakukan terhadap parameter yang menjadi indikator tingkat kesegaran ikan, yaitu meliputi: Uji organoleptik mencakup kenampakan mata, insang, epidermis, dinding perut, sayatan otot, dan bau untuk ikan basah, serta rasa, bau, dan tekstur untuk ikan kukus. Analisis kimia (TVB, TMA, pH, Proksimat), dan Analisis Mikrobiologis (jumlah bakteri Aerob, Anaerob, Gram positif dan Gram negatif).

\section{Rancangan Percobaan}

Penelitian dirancang menggunakan Rancangan Percobaan Acak Lengkap dalam pola Faktorial $(3 \times 2 \times 4)$ dengan 2 ulangan. Data diolah dengan analisis 
ragam untuk mengetahui pengaruh perlakuan, dan dilanjutkan dengan uji Duncan bila terdapat perbedaan yang nyata antar perlakuan. Disamping itu juga digunakan analisis regresi untuk melihat hubungan antar parameter yang terkait (Steel and Torrie, 1980).

\section{HASIL DAN PEMBAHASAN}

\section{Penelitian Tahap Pertama}

\section{- Pemilihan konsentrasi $\mathrm{CO}_{2}$ optimum}

Konsentrasi $\mathrm{CO}_{2}$ optimum ditentukan berdasarkan hasil uji organoleptik (ikan basah) menggunakan panelis yang terlatih dan berpengalaman, dengan hasil seperti tertera pada Tabel 1.

Tabel 1. Perubahan nilai organoleptik basah ikan kakap merah segar selama penyimpanan

Table 1. Changes of organoleptik scores of fresh red snapper during storage

\begin{tabular}{|c|c|c|c|c|c|}
\hline \multirow[t]{2}{*}{$\begin{array}{c}\text { Konsentrasi } \mathrm{CO}_{2} \\
\text { Concentration of } \mathrm{CO}_{2}\end{array}$} & \multicolumn{5}{|c|}{$\begin{array}{l}\text { Lama penyimpanan (hari) } \\
\text { Storage period (day) }\end{array}$} \\
\hline & 0 & 5 & 10 & 15 & 20 \\
\hline $100 \%$ & 4,1 & 3,5 & 3,9 & 3,5 & 3,2 \\
\hline $80 \%$ & 4,1 & 3,6 & 3,6 & 3,1 & 3,1 \\
\hline $60 \%$ & 4,1 & 3,3 & 3,8 & 3,0 & 3,1 \\
\hline $50 \%$ & 4,1 & 3,3 & 3,5 & 3,0 & 3,0 \\
\hline $40 \%$ & 4,1 & 3,7 & 3.6 & 3,3 & 3,0 \\
\hline $30 \%$ & 4,1 & 3,5 & 3,6 & 3,1 & 2,6 \\
\hline
\end{tabular}

Keterangan: rata-rata dari nilai kenampakan, tekstur, bau dan rasa dari ikan basab dan kukus. Nilai berkisar dari 5 (terbaik) - 1 (terjelek) dengan nilai batas penolakan 2,5

Note: $\quad$ mean of texture, appearance, odour, and flavour of both raw fish and steamed fish. Scores range from 5 (the best) to 1 (the worst) with borderline at 2.5

Semua perlakuan sampai akhir penyimpanan masih berada di atas batas penolakan. Walaupun terdapat perbedaan nilai penerimaan panelis antar perlakuan, tetapi secara statistik tidak terdapat perbedaan yang nyata antara semua perlakuan. Berdasarkan hal di atas, ditetapkan konsentrasi $\mathrm{CO}_{2}$ yang optimum untuk mempertahankan daya awet ikan kakap merah adalah antara $40 \%$ dan $60 \%$. Pertimbangannya adalah pengaruhnya terhadap daya awet ikan tidak berbeda dengan konsentrasi $\mathrm{CO}_{2}$ yang lebih tinggi sementara jumlah kebutuhan $\mathrm{CO}_{2}$ yang diperlukan lebih sedikit. Sedangkan lama penyimpanan yang akan digunakan pada penelitian lanjutan ditetapkan 21 hari. 


\section{Penelitian Tahap Kedua}

\section{- Perubahan organoleptik}

Secara analisis sidik ragam, ternyata hanya perlakuan konsentrasi $\mathrm{CO}_{2}$ dengan lama penyimpanan dan interaksinya yang menyebabkan perubahan nilai organoleptik, sedangkan variasi jenis kemasan (OPP dan PVC) ternyata sama sekali tidak mempengaruhi perubahan nilai organoleptik selama penyimpanan.

Selama 14 hari pertama penyimpanan, nilai organoleptik ikan (baik ikan mentah maupun dikukus) menurun secara linier dan hampir tidak terdapat adanya perbedaan di antara perlakuan (Gambar 1 dan 2). Setelah hari ke-14 sampai pada akhir penyimpanan, nilai organoleptik perlakuan kontrol/udara turun dengan tajam melewati batas penolakan, perlakuan $\mathrm{CO}_{2} 40 \%$ berada pada nilai batas penolakan, sedangkan perlakuan $\mathrm{CO}_{2} 60 \%$ masih berada di atas batas penolakan.

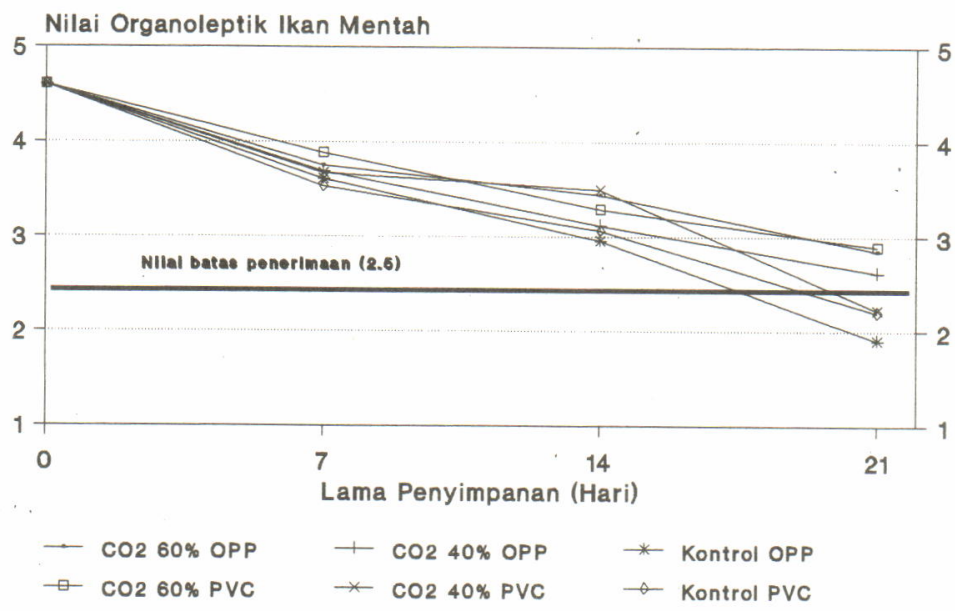

Gambar 1. Perubahan nilai organoleptik ikan kakap merah (mentah) selama penyimpanan secara MAS pada $2^{\circ} \mathrm{C}$

Figure 1. Changes of organoleptic value of raw red snapper during modified atmosphere storage at $2^{\circ} \mathrm{C}$

Hasil analisis regresi antara penerimaan panelis dan lama penyimpanan untuk ikan mentah dan ikan kukus menunjukkan adanya pola penurunan yang berbeda. Pada perlakuan yang menggunakan kemasan PVC, perubahan organoleptik ikan mentah menunjukkan kecenderungan pola linier yang kuat (dengan nilai 'r' antara 0,97-0,99) dan laju penurunan yang tinggi (dengan nilai 'b' berturut-turut 0,0806; 0,0986; dan 0,1171 untuk perlakuan $\mathrm{CO}_{2} 60 \%, 40 \%$, dan kontrol), sedangkan pada ikan kukus, pola linier mempunyai nilai 'r' yang 
sedikit lebih rendah (antara 0,95-0,96) dengan laju penurunan yang lebih lambat (nilai 'b' untuk $\mathrm{CO}_{2} 60 \%, 40 \%$, dan kontrol berturut-turut sebesar 0,$1289 ; 0,1916$; dan 0,2441). Data ini memberikan indikasi adanya dua hal yang menarik. Pertama ialah bahwa untuk semua perlakuan, perubahan kenampakan (yang diamati dalam keadaan mentah) cenderung lebih cepat dibandingkan dengan perubahan bau, rasa, dan tekstur (yang diamati setelah dikukus). Yang kedua adalah bahwa semakin tinggi konsentrasi $\mathrm{CO}_{2}$, semakin lambat pula penurunan mutu organoleptik baik dilihat dari kenampakan maupun bau, rasa, dan tekstur ikan. Dengan menggunakan persamaan regresi di atas dan nilai batas penolakan yang telah ditetapkan, secara teoritis umur simpan ikan dapat diperkirakan, yakni berturut-turut 25, 20, dan 17 hari untuk perlakuan $\mathrm{CO}_{2}$ $60 \%, 40 \%$, dan kontrol bila didasarkan atas kenampakannya, serta 28,21 , dan 17 hari bila didasarkan atas perubahan bau, rasa, dan teksturnya. Di sini terlihat bahwa pada $\mathrm{CO}_{2} 60 \%$ terdapat perbedaan umur simpan selama 3 hari antara ikan kukus dan ikan mentah, sedangkan untuk $\mathrm{CO}_{2} 40 \%$, perbedaan tersebut hanya 1 hari. Pada perlakuan kontrol bahkan tidak ada perbedaan sama sekali. $\mathrm{Hal}$ ini menunjukkan bahwa semakin tinggi kadar $\mathrm{CO}_{2}$ semakin panjang umur simpan ikan, khususnya dilihat dari bau, rasa, dan teksturnya.

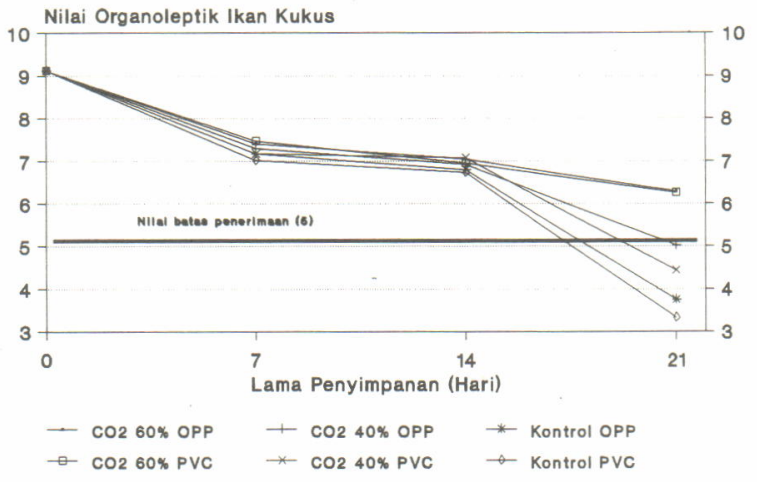

Gambar 2. Perubahan nilai organoleptik ikan kakap merah (kukus) selama penyimpanan secara MAS pada $2^{\circ} \mathrm{C}$

Figure 2. Changes of organoleptic value cooked red snapper during modified atmosphere storage at $2^{\circ} \mathrm{C}$

\section{- Total Volatile Bases (TVB)}

Seperti halnya pada nilai organoleptik, nilai TVB ternyata berubah sesuai dengan konsentrasi $\mathrm{CO}_{2}$ yang diberikan. Akan tetapi jenis kemasan ternyata tidak berpengaruh terhadap pola perubahan TVB.

Kandungan TVB cenderung naik selama penyimpanan (Gambar 3). Kandungan TVB terendah yang dicapai pada akhir penyimpanan yaitu pada perlakuan konsentrasi $\mathrm{CO}_{2} 60 \%(22.584 \mathrm{mgN} \%)$ dan masih berada di bawah 
batas maksimum kesegaran ikan yang dapat diterima yaitu $30 \mathrm{mgN} \%$ (Connell, 1980).

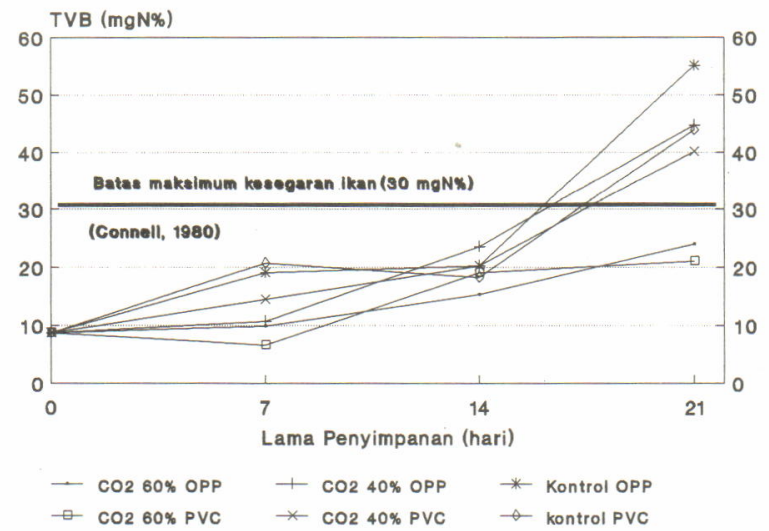

Gambar 3. Perubahan TVB ikan kakap merah segar selama penyimpanan secara MAS pada $2^{\circ} \mathrm{C}$

Figure 3. Changes of TVB content of fresh red snapper during modified atmosphere storage at $2^{\circ} \mathrm{C}$

Menurut Banks et al. (1980), konsentrasi $\mathrm{CO}_{2}$ yang ditinggikan akan dapat menghambat aktivitas metabolisme bakteri, yang mengakibatkan kematian/ terganggunya pertumbuhan bakteri tersebut. Keadaan ini akan mempengaruhi produksi TVB, karena TVB merupakan hasil degradasi protein dan derivat-derivatnya oleh aktivitas bakteri.

\section{- Trimethylamine (TMA)}

Pola perubahan TMA ternyata juga sesuai dengan perubahan nilai organoleptik dan TVB, yaitu mengikuti konsentrasi $\mathrm{CO}_{2}$ yang diberikan tanpa dipengaruhi oleh jenis kemasan.

Nilai TMA terendah pada akhir penyimpanan diperoleh pada perlakuan konsentrasi $\mathrm{CO}_{2} 60 \%$ kemasan PVC (9.53 mgN\%) dan masih berada jauh di bawah batas maksimum kesegaran ikan yang dapat diterima yaitu $15 \mathrm{mgN} \%$ (Connell, 1980).

Perkembangan jumlah TMA praktis mengikuti pola yang sama dengan TVB (Gambar 4), karena TMA merupakan salah satu senyawa turunan yang mengkontribusi TVB, di samping senyawa lain seperti DMA, ammonia dan amina-amina lainnya (Perez Villarreal and Howgate, 1987). TMA adalah hasil reduksi dari Trimetilamin oksida (TMAO) oleh aktivitas bakteri. Kandungan akan meningkat pada ikan yang mengarah ke pembusukan (Wheaton and Lawson, 1985). 


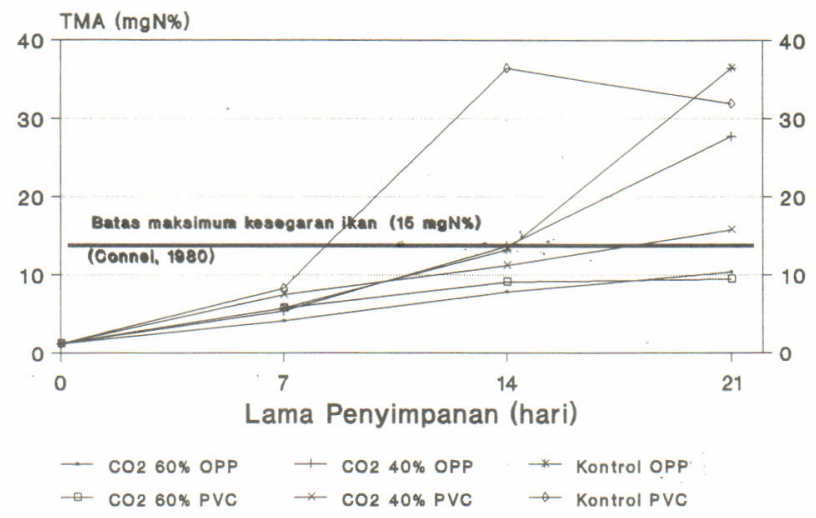

Gambar 4. Perubahan TMA ikan kakap merah segar selama penyimpanan secara MAS pada $2^{\circ} \mathrm{C}$

Figure 4. Changes of TMA content of fresh red snapper during modified atmosphere storage at $2^{\circ} \mathrm{C}$

\section{- Nilai pH}

Selama penyimpanan, nilai $\mathrm{pH}$ ikan pada semua perlakuan mengalami kenaikan (Gambar 5) tanpa dipengaruhi oleh konsentrasi $\mathrm{CO}_{2}$ maupun jenis kemasan. Walaupun demikian, nilai $\mathrm{pH}$ terendah $(6,9)$ pada akhir penyimpanan adalah pada perlakuan $\mathrm{CO}_{2} 60 \%$.

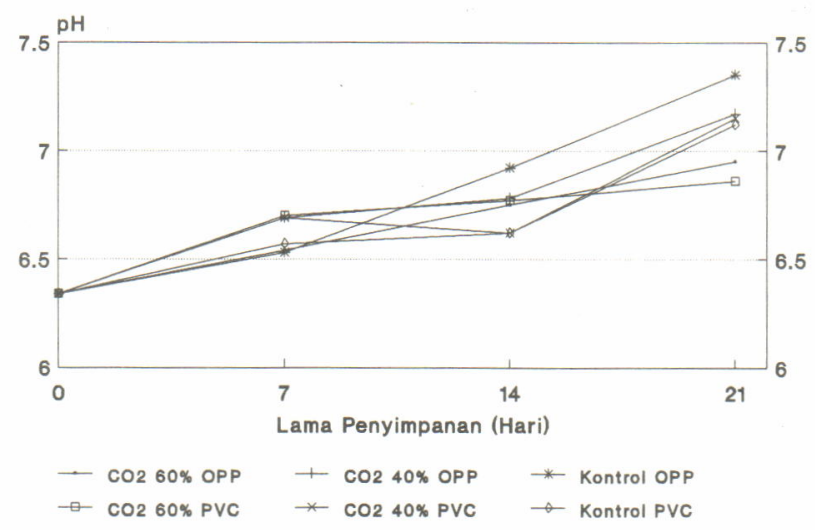

Gambar 5. Perubahan $\mathrm{pH}$ ikan kakap merah segar selama penyimpanan secara MAS pada $2^{\circ} \mathrm{C}$

Figure 5. Changes of $p H$ value of fresh red snapper during modified atmosphere storage at $2^{\circ} \mathrm{C}$ 
Naiknya nilai pH selama penyimpanan, antara lain disebabkan karena meningkatnya jumlah senyawa-senyawa basa dalam tubuh ikan, sebagai hasil penguraian daging ikan oleh aktivitas bakteri dan enzim, seperti senyawasenyawa trimetilamin (TMA), dimetilamin (DMA), amonia dan amina- amina lainnya (Nair and Lahiry, 1968).

\section{- Analisis Proksimat}

Perubahan komposisi kimia ikan selama penyimpanan tidak begitu besar, dan praktis tidak terdapat perbedaan yang berarti antara ketiga perlakuan. Pada akhir penyimpanan, terlihat kadar protein, lemak dan kadar abu mengalami penurunan, yang mungkin disebabkan oleh kadar air yang mengalami sedikit peningkatan dari keadaan awal (Gambar 6).

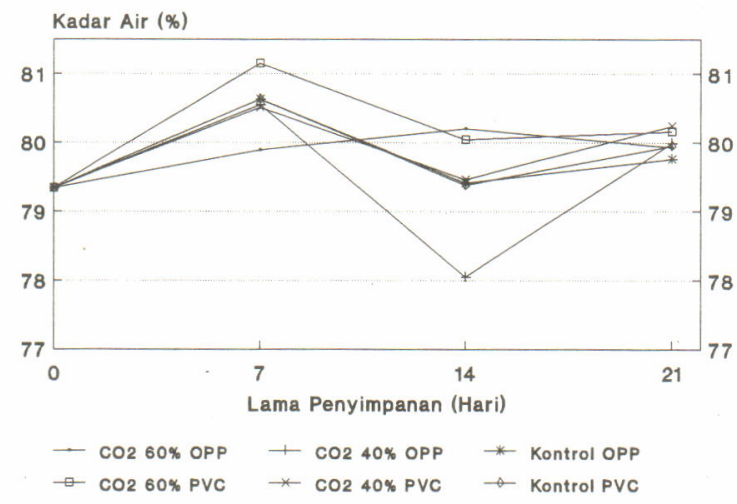

Gambar 6. Perubahan kadar air ikan kakap merah segar selama penyimpanan secara MAS pada $2^{\circ} \mathrm{C}$

Figure 6. Changes of moisture content of fresh red snapper during modified atmosphere storage at $2^{\circ} \mathrm{C}$

Kandungan protein ikan dengan perlakuan $\mathrm{CO}_{2} 60 \%, \mathrm{CO}_{2} 40 \%$ dan kontrol/udara pada akhir penyimpanan terlihat masih cukup tinggi, yaitu berturut-turut $16,63 \%, 16,26 \%$ dan $16,22 \%$. Sedangkan kandungan lemaknya cukup rendah, yaitu berturut-turut $0,48 \%, 0,56 \%$ dan $0,32 \%$ (Tabel 2).

\section{- Kondisi Bakterial}

Dalam penelitian ini diamati jumlah bakteri aerobik maupun anaerobik untuk melihat kondisi bakterial produk selama penyimpanan mengingat kondisi kemasan yang memungkinkan pertumbuhan kedua jenis bakteri tersebut. Di samping itu juga dilakukan pengamatan terhadap jumlah bakteri gram positif dan gram negatif, untuk mengetahui perubahan komposisi bakteri. Meskipun pengaruh $\mathrm{CO}_{2}$ bervariasi menurut spesies bakteri, pada 
umumnya bakteri gram negatif lebih dihambat daripada gram positif. Karena biasanya pada ikan terdapat bakteri gram negatif lebih banyak daripada gram positif, maka pemberian $\mathrm{CO}_{2}$ akan dapat menghambat pembusukan ikan. Sistem pengemasan modifikasi atmosfir dengan $\mathrm{CO}_{2}$ dapat menyebabkan perubahan dari dominasi bakteri gram negatif seperti Pseudomonas menjadi bakteri gram positif seperti Lactobacillus, yang kemungkinan disebabkan oleh suasana asam (adanya asam karbon $/ \mathrm{H}_{2} \mathrm{CO}_{3}$ ) dan kondisi anaerobik (Banks et.al., 1980). Kemungkinan tumbuhnya Clostridium botulinum kecil dalam percobaan ini karena suhu penyimpanan yang cukup rendah, jauh di bawah persyaratan minimum untuk pertumbuhan C.botulinum, yaitu $12^{\circ} \mathrm{C}$.

Tabel 2. Komposisi Kimia Ikan Kakap Merah Segar sebelum Awal dan pada Akhir Penyimpanan Secara MAS pada Suhu $2^{\circ} \mathrm{C}$

Table 2. Chemical composition of fresh red snapper before and after storage by MAS at $2{ }^{\circ} \mathrm{C}$

\begin{tabular}{|c|c|c|c|c|c|}
\hline \multirow{2}{*}{\multicolumn{2}{|c|}{$\begin{array}{l}\text { Komposisi kamia } \\
\text { Obemical composition }\end{array}$}} & \multirow{2}{*}{$\begin{array}{l}\text { Sebelum } \\
\text { penyimpanan } \\
\text { Before storage }\end{array}$} & \multicolumn{3}{|c|}{$\begin{array}{l}\text { Akhir penyimpanan (21 hari) } \\
\text { After } 21 \text { day storage }\end{array}$} \\
\hline & & & $\mathrm{CO}_{2} 60 \%$ & $\mathrm{CO}_{2} 40 \%$ & $\begin{array}{l}\text { Kontrol } \\
\text { Control }\end{array}$ \\
\hline Kadar air (Moisture) & $\%$ & 79,34 & 80,05 & 80,12 & 79,58 \\
\hline Kadar abu $(A s h)$ & $\%$ & 1,92 & 1,51 & 1,38 & 1,39 \\
\hline Protein & $\%$ & 18,00 & 16,63 & 16,26 & 16,22 \\
\hline Lemak (Fat) & $\%$ & 0,63 & 0,48 & 0,56 & 0,32 \\
\hline
\end{tabular}

Perkembangan jumlah bakteri aerob selama penyimpanan terlihat berbeda jelas antar perlakuan, terutama pada 7 hari pertama penyimpanan. Jumlah bakteri pada perlakuan $\mathrm{CO}_{2} 60 \%$ dan $\mathrm{CO}_{2} 40 \%$ turun sekitar $1-2$ siklus log dari jumlah awal, yaitu berturut-turut menjadi $9,12 \times 10^{3} \mathrm{sel} / \mathrm{g}$ dan $7.58 \times 10^{4} \mathrm{sel} / \mathrm{g}$. Sebaliknya pada saat yang sama perlakuan kontrol/udara meningkat sekitar 1,5 siklus log, yaitu menjadi hampir $10^{7} \mathrm{sel} / \mathrm{g}$ untuk kemudian terus meningkat hingga akhir penyimpanan (Gambar 7). Pada perlakuan $\mathrm{CO}_{2}$ dan jenis kemasan tampak pula sedikit peningkatan jumlah bakteri aerob, yang kemungkinan besar disebabkan terjadinya transmisi gas melalui kemasan. Walaupun demikian, jumlah bakteri terendah pada akhir penyimpanan adalah pada perlakuan $\mathrm{CO}_{2} 60 \%$ kemasan OPP $\left(1,66 \times 10^{5} \mathrm{sel} / \mathrm{g}\right)$. Hal ini disebabkan oleh karena level $\mathrm{CO}_{2}$ yang ditinggikan bersifat "bakterisidal" atau dapat membunuh bakteri yang sudah ada sebagai flora awal pada ikan (Jensen et al., 1980). Bagaimana mekanisme $\mathrm{CO}_{2}$ mempengaruhi pertumbuhan bakteri secara pasti, belum dapat dijelaskan dengan sempurna (Statham, 1984). Namun menurut Banks et al. (1980), apabila tekanan oksigen berkurang, akan menyebabkan perubahan kemampuan tipe bakteri aerob sempurna (obligat aerobic) untuk tumbuh. 


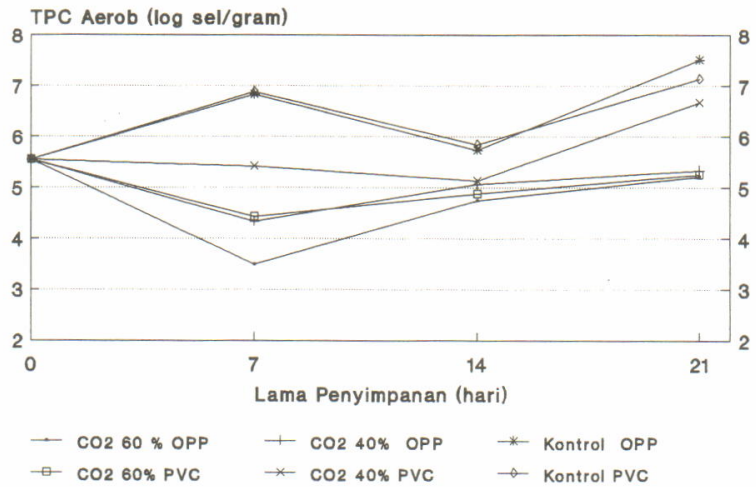

Gambar 7. Perubahan jumlah bakteri aerob ikan kakap merah selama penyimpanan secara MAS pada $2^{\circ} \mathrm{C}$

Figure 7. Changes of aerobic bacterial count of fresh red snapper during modified atmosphere storage at $2^{\circ} \mathrm{C}$

Perlakuan konsentrasi $\mathrm{CO}_{2}$ dan jenis kemasan ternyata berpengaruh terhadap jumlah bakteri anaerob. Selama penyimpanan, perkembangan jumlah bakteri anaerob setiap perlakuan, terlihat mengikuti pola yang berkebalikan dengan bakteri aerob (Gambar 8). Terlihat pada gambar tersebut bahwa dengan perlakuan modifikasi atmosfir, jumlah bakteri anaerob selalu meningkat selama penyimpanan, sebaliknya pada perlakuan kontrol, bakteri anaerob mulai menurun jumlahnya setelah hari ke-14.

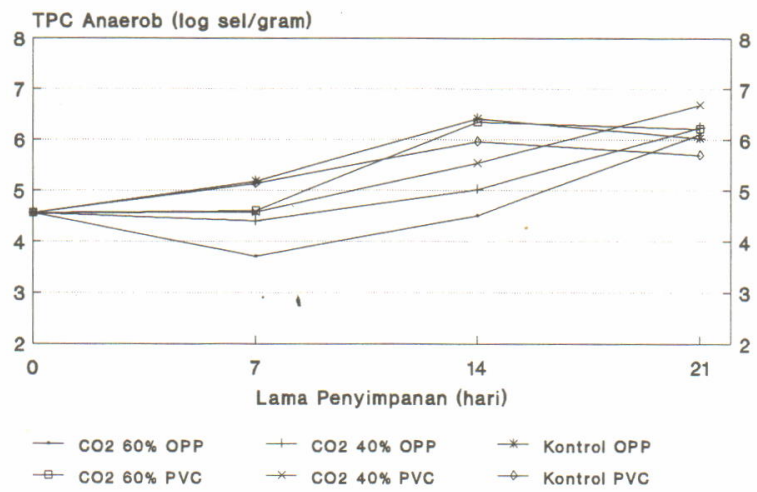

Gambar 8. Perubahan jumlah bakteri anaerob ikan kakap merah selama penyimpanan secara MAS pada $2^{\circ} \mathrm{C}$

Figure 8. Changes of anaerobic bacterial count of fresh red snapper during modified atmosphere storage at $2^{\circ} \mathrm{C}$ 
Scott et al. (1984), menyatakan bahwa jumlah bakteri anaerob pada fillet ikan "snapper" yang disimpan dalam atmosfir $\mathrm{CO}_{2}$, tidak memperlihatkan suatu "lag phase" yang jelas, tetapi meningkat secara linier-log selama 14 hari periode penyimpanan. Lebih lanjut dijelaskan, antar perlakuan $\mathrm{CO}_{2}$ (vakum, tanpa vakum, dan $\mathrm{CO}_{2}$ ) pada ikan yang sama, juga tidak memperlihatkan perbedaan jumlah total bakteri anaerob yang jelas. Ditemukan lebih kurang $74 \%$ bakteri yang diisolasi di bawah kondisi anaerob, adalah tergolong fakultatif anaerob, yang dapat tumbuh cukup baik pada kondisi aerob.

Perlakuan konsentrasi $\mathrm{CO}_{2}$ dan jenis kemasan ternyata juga berpengaruh terhadap perkembangan bakteri gram positif. Selama penyimpanan, jumlah bakteri gram positif cenderung meningkat, kecuali perlakuan $\mathrm{CO}_{2} 60 \%$ yang terlihat pada 7 hari pertama penyimpanan justru mengalami penurunan sekitar 1 siklus log (Gambar 9). Meskipun secara kuantitas terdapat penurunan jumlah bakteri gram positif, tetapi secara proporsi terhadap jumlah bakteri total justru mengalami peningkatan dari 1,25\% ( 0 hari) menjadi $6,77 \%$ ( 7 hari). Sebaliknya pada perlakuan kontrol mengalami penurunan dari $1,25 \%$ ( 0 hari) menjadi 0,559\% (7 hari). Hal ini sejalan dengan Banks et al. (1980), yang menyatakan bahwa ikan segar yang disimpan dalam atmosfir $\mathrm{CO}_{2}$ yang ditinggikan, akan memperlihatkan peningkatan proporsi bakteri gram positif terhadap jumlah bakteri total dan sebaliknya pada ikan yang disimpan dalam kondisi tanpa $\mathrm{CO}_{2}$ (udara normal).

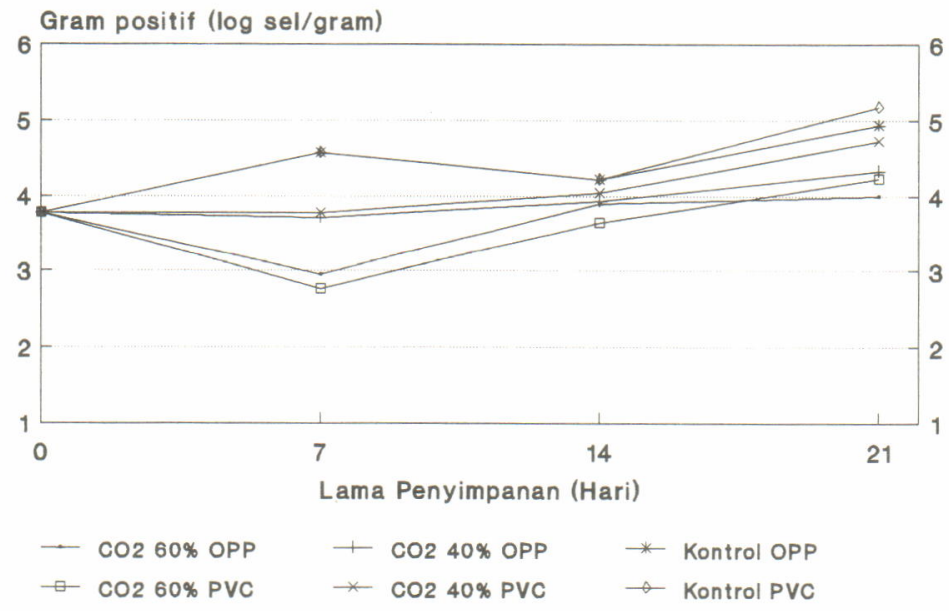

Gambar 9. Perubahan jumlah bakteri gram positif ikan kakap merah segar selama penyimpanan secara MAS pada $2^{\circ} \mathrm{C}$

Figure 9. Changes of gram positive bacterial count of fresh red snapper during modified atmosphere storage at $2^{\circ} \mathrm{C}$

Perkembangan jumlah bakteri gram negatif selama penyimpanan praktis mengikuti pola yang sama dengan jumlah bakteri aerobik. Pada 7 hari pertama, perlakuan $\mathrm{CO}_{2}$ memperlihatkan penurunan (terutama $\mathrm{CO}_{2} 60 \%$, menurun 2 
siklus log) dan sebaliknya pada perlakuan kontrol justru terjadi peningkatan yang kemudian menurun kembali hingga akhir pengamatan (Gambar 10). Proporsi bakteri gram negatif berfluktuasi selama penyimpanan, seperti yang ditemukan oleh Banks et al. (1980) pada ikan "trout". Bakteri gram negatif merupakan kelompok yang aktif sebagai bakteri pembusuk pada ikan (Banks et al., 1980).

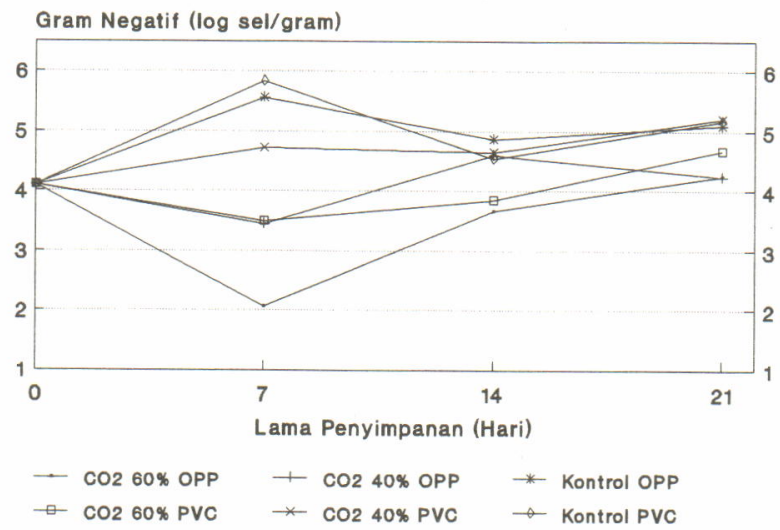

Gambar 10. Perubahan jumlah bakteri gram negatif ikan kakap merah segar selama penyimpanan secara MAS pada $2^{\circ} \mathrm{C}$

Figure 10. Changes of gram negative bacterial count of fresb red snapper during modified atmosphere storage at $2^{\circ} \mathrm{C}$

\section{KESIMPULAN}

Penggunaan $\mathrm{CO}_{2}$ dengan konsentrasi lebih tinggi dari kondisi normal berpengaruh sangat nyata dalam mempertahankan mutu ikan kakap merah segar secara organoleptik, dan didukung oleh parameter mutu secara kimiawi dan mikrobiologis.

Penggunaan jenis kemasan plastik OPP dan PVC hanya berpengaruh terhadap mutu mikrobiologis (TPC, bakteri anaerob, bakteri gram negatif dan positif), tetapi tidak mempengaruhi mutu organoleptik serta mutu kimianya.

Konsentrasi $\mathrm{CO}_{2}$ yang cocok digunakan dalam mempertahankan daya awet ikan kakap merah segar secara MAS pada suhu $2^{\circ} \mathrm{C}$ adalah $60 \%$, menggunakan kemasan OPP atau PVC, dengan umur simpan yang lebih dari 21 hari.

\section{SARAN}

Disarankan untuk melakukan penelitian lebih lanjut dengan memperhatikan segi ekonomisnya dan aspek kualitatif dari kemungkinan pertumbuhan bakteri patogen. 


\section{Ucapan Terima Kasih}

- Diucapkan terima kasih kepada Kepala dan Staf Peneliti serta Karyawan Instalasi Penelitian Perikanan Laut Slipi atas bantuan berupa fasilitas maupun tenaga serta sumbangan pemikiran yang diberikan.

- Penghargaan yang sama juga diberikan kepada Kepala dan Staf Pusbangtepa IPB atas bantuannya.

- Ucapan terima kasih juga diberikan kepada Direktur dan Karyawan PT. Aneka Gas atas kerja sama yang baik.

\section{DAFTAR PUSTAKA}

Banks H., R.Nickleson and G.Finne, 1980. Shelf-life studies on carbon dioxide packaged Finfish from the Gulf of Mexico. J. Food Sci. 45: 157-162.

Cann D.C., 1988. Modified atmosphere packaging of fishery products. Infofish International I: 37-39.

Connell J.J., 1980. Control of fish quality, $2^{\text {nd }}$. Fishing News Book Ltd., Farnham, Surrey, England.

Jensen M.H., A.Petersen, E.H.Roge and A.Jepsen, 1980. Storage of chilled cod under vacuum and at various concentrations of carbon dioxide In J.J. Connel (ed.) Advances in Fish Science and Technology. Fishing News Books Ltd. Farnham Surrey, England. p: 294 - 297.

Lannelongue M., G.Finne, M.O.Hanna, R.Nickleson and G.Vanderzant, 1982. Storage characteristics of Brown shrimp (Penaeus azteus) stored in retail packages containing $\mathrm{CO}_{2}$-enriched atmosphere. J. Food Sci. 47: 911 -923.

Nair R.B. and Lahiry N.L., 1968. Factors affecting the quality of fresh fish and its retention by: J. Food Sci. Technol. 5.

Perez Villareal B. and Howgate P., 1987. Spoilage of European hake (merbiccius merbiccius) in ice. J. of Food Sci.

Scott D.N., G.C.Fletcher dan G.Summers, 1984. Modified atmosphere and vacuum packing of snapper fillets. Food Tecknol. Australia 36 (7) : 330 - 34.

Statham J.A., 1984. Modified asmosphere storage of fisheries products: the state of the art. Food Technol. Australia. 36 (5) : 233-9.

Steel R.G.P. and J.H.Torrie, 1980 Principles and procedures of statistics, a biometrical approach, $2^{\text {nd }}$ edition. McGraw Hill, Kogahusha Ltd., Tokyo. 633 p.

Wheaton F.W. and T.B.Lawson, 1985. Processing aquatic food products. Willey Interscience Publishing, New York. 